\title{
A Study of the Influence of Guide Vane Design to Increase Savonius Wind Turbine Performance
}

\author{
Elsadic Salim ${ }^{1}$, Waled Yahya ${ }^{1}$, D. Danardono ${ }^{1} \&$ D. A. Himawanto ${ }^{1}$ \\ ${ }^{1}$ Mechanical Engineering Department, Sebelas Maret University, Surakarta, Indonesia \\ Correspondence: D. Danardono, Mechanical Engineering Department, Sebelas Maret University, Surakarta, \\ Indonesia. Tel: 62-857-2865-1030. E-mail: Els792012@yahoo.com
}

Received: April 24, 2015

Accepted: June 2, 2015

Online Published: September 30, 2015

doi:10.5539/mas.v9n11p222

URL: http://dx.doi.org/10.5539/mas.v9n11p222

\begin{abstract}
This work experimentally studied the influence of guide vane design to increase Savonius rotor performance. Guide vane is one of additional device that its function is for directing wind stream onto concave blade and deserves as obstacle of the wind that flowing onto convex blade. That way increased wind speeds to the rotor, consequently it produced higher power coefficient and the Savonius rotor performed better performance. Four designs of guide vane were arranged in this study. They are basic design of guide vane and basic design of guide vane that added a tilt angle on the top and bottom sides by $15^{\circ}, 30^{\circ}$, and $45^{\circ}$. The result concluded that guide vane affects the performance of Savonius rotor. The power that generated by the rotor with guide vanes increase significantly compared with Savonius rotor without guide vane. The maximum improvement was attained up to $65.89 \%$.
\end{abstract}

Keywords: wind energy, wind turbine, savonius rotor, guide vane, savonius rotor performance

\section{Introduction}

Renewable energy of wind interest increases as alternative energy to fulfill the increasing of energy needs over the world. The wind energy is basically the kinetic energy of large masses of air moving over the surface of earth. The wind turbine receives the kinetic energy, then transforms it into electrical forms (Sathyajith, 2006). Savonius wind turbine has been tested to be effective devices to extract energy from the wind. It has been used to generate mechanical and electrical energy at a range of scales, from small-scale through the large-scale electricity production (Tong, 2010). It has simple structure, relatively low operating speeds, and an ability to capture wind from any directions.

There are many studies that conducted to determine the efficiency of Savonis wind turbine. These studies were carried out to understand the influence of various parameters and modification of Savonius wind turbine by researchers in attaining maximum performance of it. An experimental study of a $180^{\circ}$ twisted helical Savonius rotor carried out by Damak et al. A helical geometry gives better performance than conventional rotor (Damak, Driss, \& Abid, 2013). Three-stage Savonius rotor that tested on wind tunnel was carried out by Hayashi et al (Hayashi, Li, \& Hara). Nasef et al examine a numerical study the effect of overlap ratio toward efficiency of Savonius rotor performance. Static torque coefficient and drag coefficient increased accordingly with the overlap ratio increasement (Nasef, El-Askary, AbdEL-Hamid, \& Gad, 2013). Kumbernuss conducted experimental investigation the effect of the overlap ratio and shift angle of double stage towards vertical axis wind turbnine (VAWT). Maldonado et al conducted a simulation study the influence of various blades geometry and gap distance between blades. Better geometry and gap distance between blades improved the $\mathrm{Cp}$ of Savonius rotor (Maldonado et al., 2014). Jeon et al was conducted a study about the effect of end plates existance with various shapes and size. As result the usage of end plates improves Cp up to $36 \%$ compared to without end plates (Jeon, Jeong, Pan, \& Ryu, 2014). N.H. Mahmoud et al carried out an experimental study to determine the most effective operation parameters on different geometries of Savonius wind turbine such as number of blades, stages, overlap ratio, aspect ratio and existence of end plates (Mahmoud, El-Haroun, Wahba, \& Nasef, 2012). Akwa et al reviewed Savonius wind turbine performance. The study shows that each Savonius rotor with different arragement affects its performance (Akwa, Vielmo, \& Petry, 2012). Experiment of wind tunnel of a two-bladed Savonius-style wind turbine introduced by Saha et al. Maximum Cp reached improvement up tp $34.8 \%$ (Roy \& Saha, 2015). 
Wind direction device is one of some ways that examined to improve the Savonius wind turbine performance. In studies of the usage of wind direction device, scientists introduced various designs of the wind direction device. Altan et al studied improvement of Savonius rotor performance with curtaining experimentally, the result shows that $\mathrm{Cp}$ of rotor with curtaining improves about $38.5 \%$ (Altan, Atılgan, \& Özdamar, 2008). Kim et al studied experimentally influence of upstream deflector on performance of straight-bladed VAWTs (Kim \& Gharib, 2013). The power of wind turbine increases significantly when the turbine placed behind the deflector. A new augmented shroud integrated with VAWT was introduced by Wong et al to improve performance of wind turbine system for urban area. This power augmented shroud could increase the performance of the VAWT significantly by increasing the wind speed (Chong, Fazlizan, Pan, \& Poh, 2010). In other study, Ogawa et al determined performance of Savonius rotor with circular guide anes. Starting characteristic was improved by placing the guide vanes around the rotor (OGAWA, TAHARA, \& SUZUKI, 1986).

The present study purposes to examine experimentally the influence of guide vane designs towards improving of Savonius performance. Four different designs of guide vane introduce in this study. They are basic design of guide vane, basic design with additional tilt angle of $15^{\circ}$, basic design with additional tilt angle of $30^{\circ}$, and basic design with additional tilt angle of $45^{\circ}$. Those various design of guide vane palced in front of a two-blades Savonius rotor with end plates on the top and bottom Savonius bucket.

\begin{tabular}{|llll}
\hline \multicolumn{2}{l}{ NOMENCLATURE } & & \\
$\mathrm{E}$ & Kinetic Energy & $\mathrm{Cp}$ & Power Coefficient \\
$\dot{m}$ & Mass flow $(\mathrm{Kg} / \mathrm{s})$ & $\mathrm{R}$ & Tip radius of Rotor $(\mathrm{m})$ \\
$v$ & Velocity $(\mathrm{m} / \mathrm{s})$ & $\lambda$ & Tip Speed Ratio \\
$\rho$ & Density $\left(\mathrm{Kg} / \mathrm{m}^{3}\right)$ & $\mathrm{N}$ & Rotational speed of Rotor (rpm) \\
$\mathrm{A}$ & Swept Area $\left(\mathrm{m}^{2}\right)$ & $\mathrm{D}$ & Diameter $(\mathrm{m})$ \\
$\mathrm{P}$ & Power $($ watt $)$ & $\mathrm{T}$ & Torque $(\mathrm{Nm})$ \\
Po & Wind Power & $\mathrm{Ct}$ & Torque Coefficient \\
$\omega$ & Angular Speed $(1 / \mathrm{s})$ & $e$ & Overlap
\end{tabular}

\section{Experimental Set Up and Procedure}

Savonius configurations with and without guide vane and with guide vanes are shown on the Figure 1. This study used two blades of Savonius wind turbine. Height of the Savonius rotor is $180 \mathrm{~mm}$. Diameter of the turbine was $20 \mathrm{~cm}$, the overlap of blades (e) was given by $1 \mathrm{~cm}$. Material of the wind turbine model used alumunium. End plates also supported the Savonius rotor model for this experiment. The end plates designed at same diameter with the Savonius blades which was $20 \mathrm{~cm}$. This experiment used six guide vanes. The guide vane configured to surround the Savonius rotor and they were setted at $60^{\circ}$.

Figure 2 Shows Savonius rotor with guide vane design configurations from side view. The basic design of guide vane was designed at same height with the Savonius turbine which is $18 \mathrm{~cm}$ for both inner and outer height. And length was given by $10 \mathrm{~cm}$, this design was designed without top and bottom discs. Second design of guide vane designed by $12 \mathrm{~cm}$ for the length and $18 \mathrm{~cm}$ for inner height. It was given additional tilt angle of $15^{\circ}$ on the top and bottom side of guide vane after the length of $3 \mathrm{~cm}$. It made slopes on both sides and giving wider height on the outer side, which was being $22.8 \mathrm{~cm}$ completed with top and bottom discs. The third design of guide vane designed with additional tilt angle of $30^{\circ}$ on the top and bottom sides after the length of $3 \mathrm{~cm}$. This design was completed with top and bottom discs. So that the outer height became $28.9 \mathrm{~cm}$. And the last design was given additional tilt angle of $45^{\circ}$ after the length of $3 \mathrm{~cm}$. This design also used top and bottom discs. The outer heigth was being $36 \mathrm{~cm}$ for this design. Guide vane used material of aluminium. The details of various designs of guide vane geometry described on Table 1.

To know the effect of guide vane in improving Savonius rotor performance determined by calculating Power, Power Coefficient $(\mathrm{Cp})$, Torque Coefficient $(\mathrm{Ct})$ and tip speed ratio $(\lambda)$. Those are given by the following equations:

$$
P_{0}=\frac{1}{2} \rho v_{1}^{3} A
$$




$$
\begin{gathered}
c_{p}=\frac{P}{P_{0}}=\frac{\frac{1}{4} \rho A\left(v_{1}^{2}-v_{2}^{2}\right)\left(v_{1}+v_{2}\right)}{\frac{1}{2} \rho v_{1}^{3} A} \\
\lambda=\frac{\omega R}{v}=\frac{\pi N D}{60 v} \\
\frac{\mathrm{C}_{p}}{\mathrm{C}_{\mathrm{T}}}=\lambda \quad \Rightarrow \frac{\mathrm{C}_{\mathrm{P}}}{\lambda}=C t
\end{gathered}
$$

It used tachometer to measure rotational speed (rpm). In the present study used WHDZ DT-2234B's tachometer which has measuring range 2.599 RPM; resolution of 0.1 RPM (2.599 RPM above)/ 1 RPM (10000 RPM above); measuring accuracy of $0.0251 \mathrm{~d}$; sample interval of 1.0 second; and time baze of $6 \mathrm{MHz}$. Anemometer was used to measure the wind speed. This study used Krisbow thermal-anemometer serie of KW0600562/ 0.6-30 m/s. The wind speed considered at average of $6.5 \mathrm{~m} / \mathrm{s}, 7.7 \mathrm{~m} / \mathrm{s}, 8.6 \mathrm{~m} / \mathrm{s}, 9.7 \mathrm{~m} / \mathrm{s}$ and $10.7 \mathrm{~m} / \mathrm{s}$. Further, the wind speed was considered stationery and constant speed and the diameter of wind was around $90 \mathrm{~cm}$. The experiments were taken place at density $(\rho)$ of 1.1614 . Swept area of the rotor (A) was $0.036 \mathrm{~m}^{2}$.

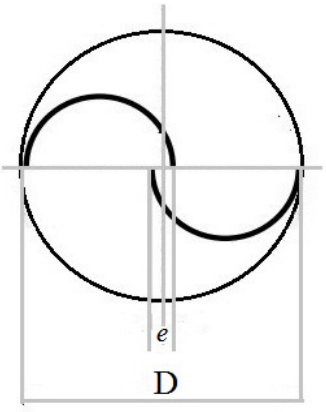

a. Savonius rotor

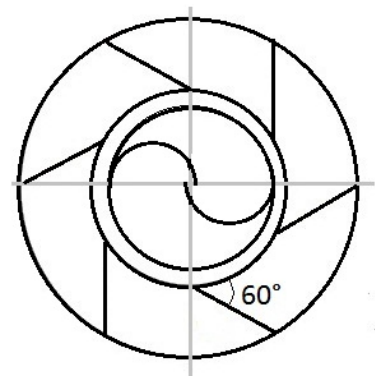

b. Savonius rotor with guide vane

Figure 1. The view scheme of Savonius rotor

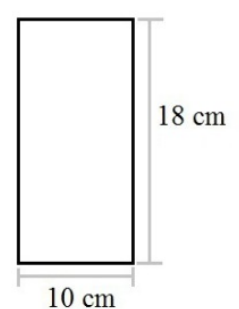

a. Basic Design
of Guide Vane

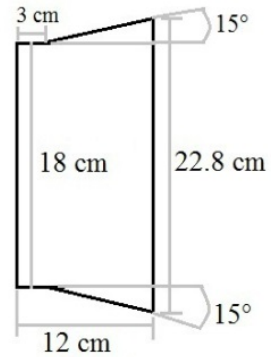

b. Basic Design plus $15^{\circ}$

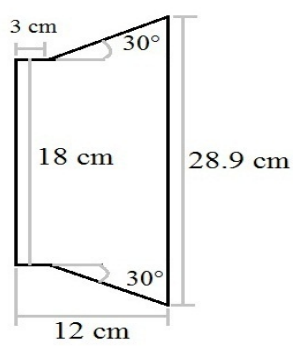

c. Basic Design plus $30^{\circ}$

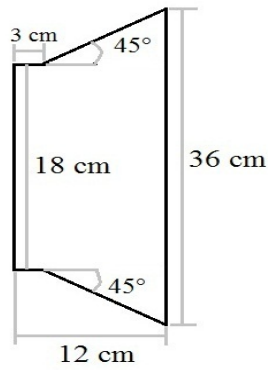

d. Basic Design plus $45^{\circ}$

Figure 2. Models of various guide vane design

Table 1. Guide vane geometry of each guide vane design.

\begin{tabular}{ccccc}
\hline Geometry & Basic Design & Basic Design+15 $^{\circ}$ & Basic Design+30 $^{\circ}$ & Basic Design+45 $^{\circ}$ \\
\hline Length & $10 \mathrm{~cm}$ & $12 \mathrm{~cm}$ & $12 \mathrm{~cm}$ & $12 \mathrm{~cm}$ \\
Inner height & $18 \mathrm{~cm}$ & $18 \mathrm{~cm}$ & $18 \mathrm{~cm}$ & $18 \mathrm{~cm}$ \\
Outer height & $18 \mathrm{~cm}$ & $22.8 \mathrm{~cm}$ & $28.9 \mathrm{~cm}$ & $36 \mathrm{~cm}$ \\
\hline
\end{tabular}




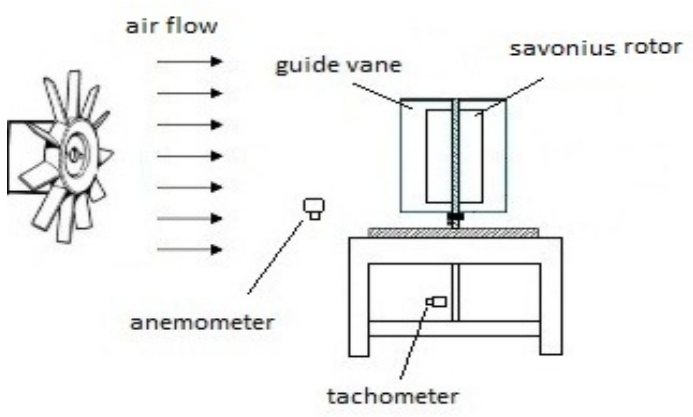

Figure 3. Experimental set up

Figure 3 shows experimental set up of this present study. The Savonius rotor placed infront of fan about $1.2 \mathrm{~m}$ away from the fan. The fan used TECO 3-phase induction motor which has two poles, $5 \mathrm{HP}, 3.7 \mathrm{KW}$, and 2865 RPM. The diameter of the blades of the fan is $50 \mathrm{~cm}$. There was also setted up tachometer and anemometer as measurement tools. The rotor placed above of supporting steel table. The fan was controled by using inverter and using anemometer to measure the expected wind speed on this experiment. The wind speeds was gotten by taking average of several spots on each experiment to determine the final wind speed values. it was done because of consideration that the wind came turbulance. Hence, the tachometer used for measuring the rotational speeds of the rotor. The rotational speed values determined by taking average of three times measurement at each velocity.

In order to compare the Savonius performance improvement by using guide vane arrangement, first experiment has done by performing experiment of Savonius rotor without guide vane. Second experiment has done by performing experiment with placing the basic guide vane design surrounded of Savonius wind rotor. The next step were done by arranging the other designs, which were basic guide vane design with additional tilt angle of $15^{\circ}, 30^{\circ}$ and $45^{\circ}$. All experiments have done at same same position and performed at same velocity of $6.5 \mathrm{~m} / \mathrm{s}$, $7.7 \mathrm{~m} / \mathrm{s}, 8.6 \mathrm{~m} / \mathrm{s}, 9.7 \mathrm{~m} / \mathrm{s}$ and $10.7 \mathrm{~m} / \mathrm{s}$ for each set of experiments. Those experiments provided actual power, current, rotational speed. The next steps were calculating $\mathrm{Cp}, \lambda, \mathrm{Ct}$.

\section{Results and Discussion}

Data that were taken from experiment are wind speed (v), rotation speed (rpm), voltage (volt), current (ampere) and power $(\mathrm{P})$. Hence these data will be calculated to know Savonius wind turbine performance. Here are the wind speed variations in the experiments:

Table 1. Frequency and Velocity

\begin{tabular}{ccc}
\hline No & Frequency $\mathbf{( H z )}$ & Velocity $(\mathbf{m} / \mathbf{s})$ \\
\hline 1 & 14 & 6,5 \\
2 & 16 & 7,7 \\
3 & 18 & 8,6 \\
4 & 20 & 9,7 \\
5 & 22 & 10,7 \\
\hline
\end{tabular}

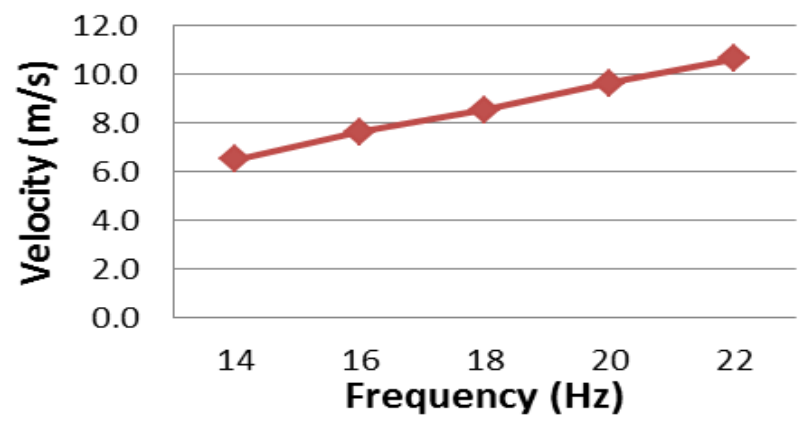

Figure 4. Frequency and Velocity 
Table 1 and figure 4 describe the result of various velocities based on the frequencies of the inverter.

Table 2. Data experiment of RPM

\begin{tabular}{cccccc}
\hline $\mathbf{V}$ & \multicolumn{5}{c}{ RPM } \\
\cline { 2 - 6 } & Without GV & Basic & Basic & Basic & Basic \\
& & Design & $+15^{\circ}$ & $+30^{\circ}$ & $+45^{\circ}$ \\
6.5 & 147 & 169 & 203 & 254 & 272 \\
7.7 & 193 & 227 & 279 & 331 & 351 \\
8.6 & 238 & 309 & 357 & 413 & 434 \\
9.7 & 315 & 393 & 452 & 512 & 529 \\
10.7 & 423 & 484 & 554 & 597 & 627 \\
\hline
\end{tabular}

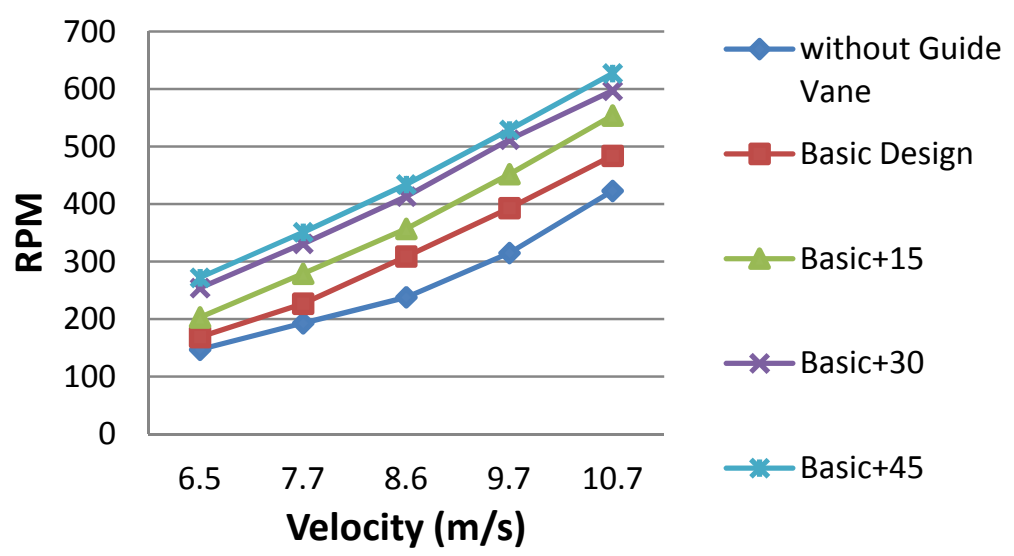

Figure 5. RPM and velocity

Table 2 shows the result of the rotational speeds based on various velocities on this study. There was increasing of the rotational speeds accordingly with the increasing of velocity. It also shows that additional of guide vane increased the rotational speeds and it happened same way on each guide vane design accordingly with increasing of tilt angle of guide vane design

Experiments have been done to determine performance of Savonius wind turbine. Those have carried out with various guide vane designs to know the effect of the design on efficiency of Savonius wind turbine performance. The performance of Savonius wind turbine with various guide vane designs compared to Savonius wind turbine without guide vane. 


\subsection{Power Coefficient}

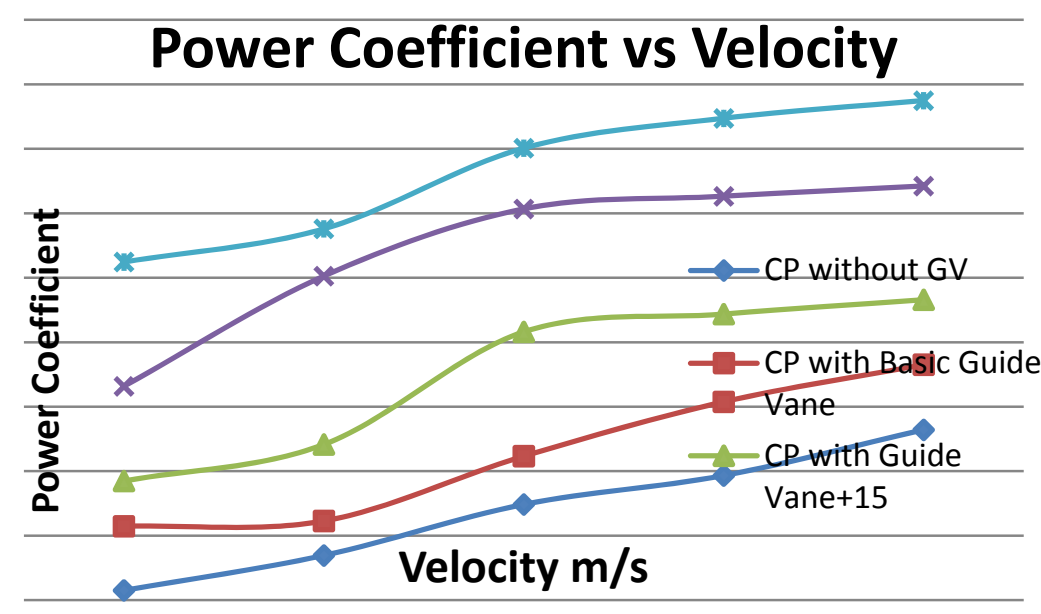

Figure 6. Correlation between Power Coefficient $(\mathrm{Cp})$ and Velocity (v)

Figure 6 shows correlation between power coefficient (Cp) and wind speeds (v) of Savonius wind turbine without guide vane and with various designs of guide vane. There is increase of power that generated by Savonius wind turbine accordingly with the increase of wind speed (v). Figure 6 also illustrates that the addition of guide vane increased the $\mathrm{Cp}$ significantly compared to wind turbine without guide vane.

The guide vane blocked up the wind into convex blade and directed the wind into concave blade of wind turbine. It consequently increased rotor rotation, so that the rotor generated higher power than the rotor without guide vane at every wind speed. The maximum $\mathrm{Cp}$ of Savonius wind turbine without guide vane was attained 0.013 at $10.7 \mathrm{~m} / \mathrm{s}$. And the maximum Cp of Savonius wind turbine with basic design of guide vane 0.018 at the same wind speed. The power increased about $27.66 \%$ based on the maximum $\mathrm{Cp}$ that produced by rotor without and with basic design of guide vane.

In other result, the maximum $\mathrm{Cp}$ was attained up to 0.023 by Savonius rotor with guide vane design that added with tilt angle $15^{\circ}$. The additional tilt angle of $15^{\circ}$ gives higher height on outer blade of the guide vane to be 22.8 $\mathrm{cm}$. It was $4.82 \mathrm{~cm}$ higher than basic design, which is $18 \mathrm{~cm}$. And the guide vane was added a top and a bottom disc. Higher height of the guide vane helped to capture more wind that coming to the rotor. And the additional top and bottom discs deflect the wind on upper and bottom part of rotor. As result, the wind directed into Savonius rotor which has $18 \mathrm{~cm}$ height. The $\mathrm{Cp}$ increased about $43.30 \%$ compared toward without guide vane rotor.

Hence other designs of guide vane were basic design with additional tilt angle of $30^{\circ}$ and $45^{\circ}$. The outer blade of guide vane of tilt angle $30^{\circ}$ increased to be $28.3 \mathrm{~cm}$ and $36 \mathrm{~cm}$ for guide vane with additional tilt angle of $45^{\circ}$. The maximum power coefficient generated by the rotor with both guide vanes were 0.032 for guide vane with additional $30^{\circ}$ tilt angle and 0.039 for the guide vane design with additional tilt angle of $45^{\circ}$. It improves about $58.86 \%$ for rotor with $30^{\circ}$ design of guide vane and up to $65.90 \%$ for the rotor with guide vane design plus tilt angle of $45^{\circ}$ compared to Savonius rotor without guide vane. 


\subsection{Tip Speed Ratio}

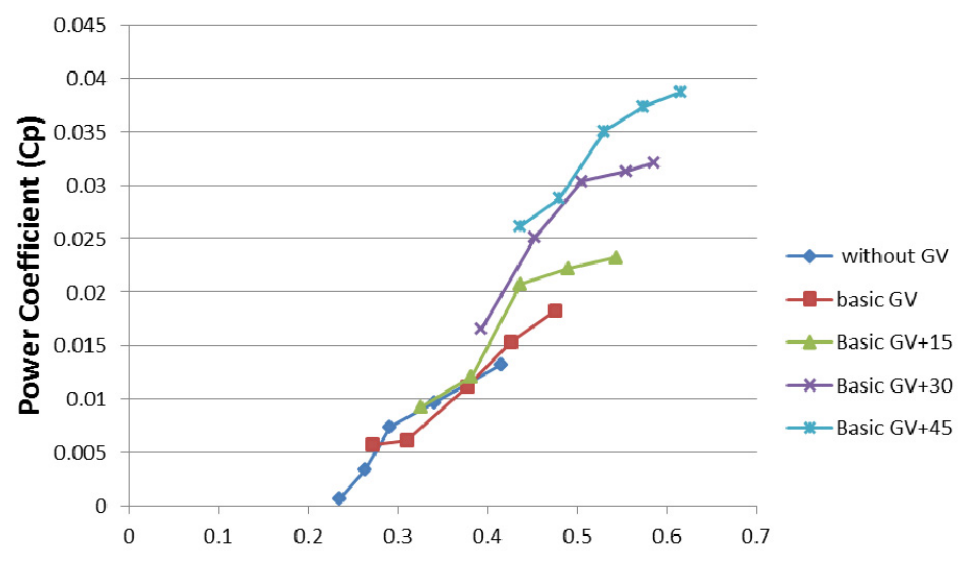

Tip Speed Ratio

Figure 7. Correlation Tip Speed Ratio $(\lambda)$ and Power Coefficient $(\mathrm{Cp})$

Figure 7 shows the relation between power coefficient (Cp) and Tip Speed Ratio (TSR) of Savonius wind turbine without guide vane and with various designs of guide vane. There are increases of $\mathrm{Cp}$ of Savonius wind turbine accordingly with the increase of TSR. Based on the above chart, maximum Cp of Savonius wind turbine without guide vane was attained 0.013 at $10.7 \mathrm{~m} / \mathrm{s}$ when TSR reached 0.42 .

The maximum Cp of Savonius wind turbine reached 0.018 while the TSR was 0.48 by additional of basic guide vane design. TSR improved about $12.6 \%$. TSR increased $23.65 \%$ on the Savonius rotor with second guide vane design by adding tilt angle of $15^{\circ}$, which is 0.54 compared to Savonius rotor without guide vane.

The next experiment used the third design of guide vane by adding tilt angle of $30^{\circ}$, the maximum TSR attained 0.59 which means increased about $29.15 \%$ compared to without guide vane rotor. The last design of guide vane with additional tilt angle of $45^{\circ}$, the maximum TSR was 0.62 and it increased about $32.54 \%$ compared to without guide vane rotor. The additional of guide vane increaced the tip speed ratio, it might be caused by the guide vane that directed the wind on to concave blade and brougt more wind to the rotor blade. As result, the ratio speed of the wind increased.

\subsection{Torque Coefficient}

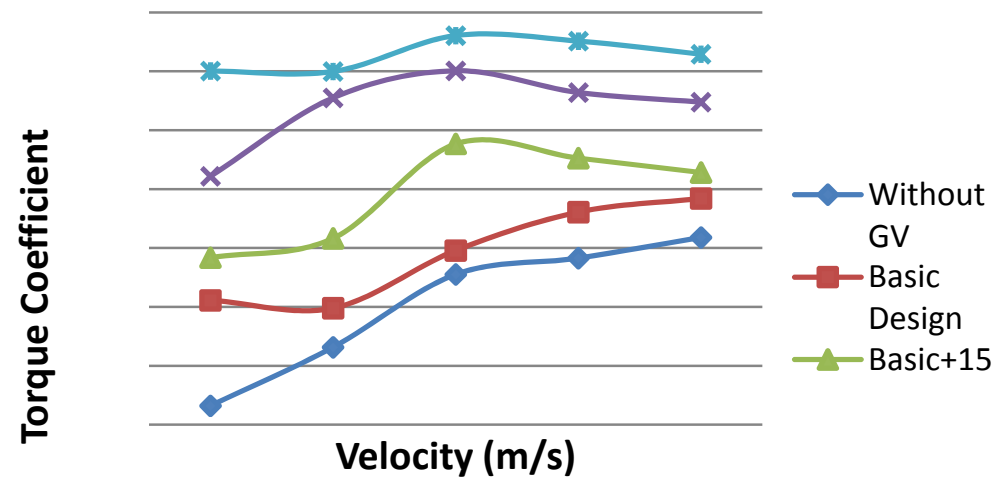

Figure 8. Correlation between Torque Coeffient and Velocity 


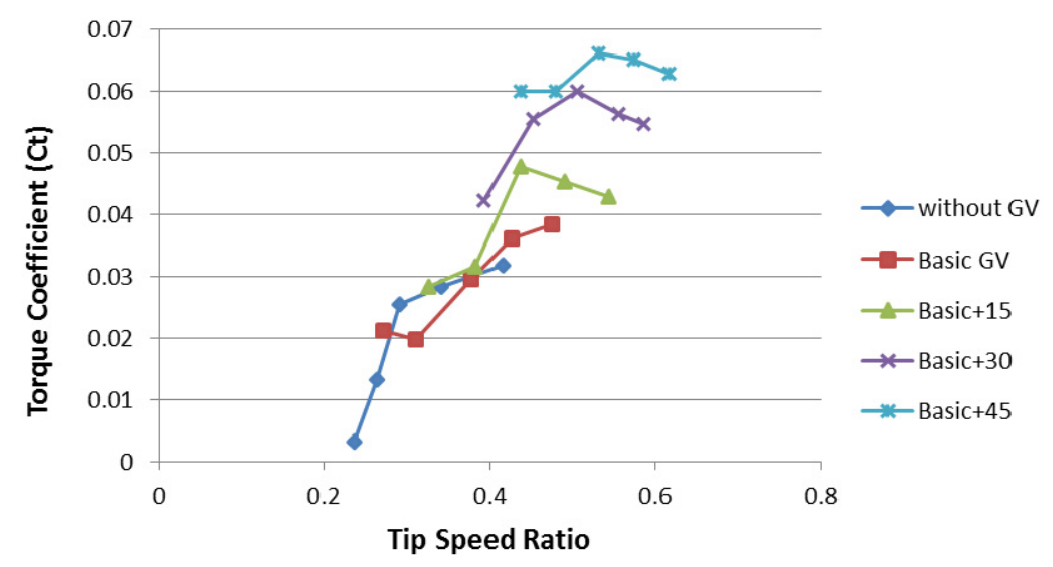

Figure 9. Correlation betweenTorque Coefficient and Tip Speed Ratio

Figure 8 and 9 illustrate correlation between coefficient torque $(\mathrm{Ct})$ and wind speed $(\mathrm{v})$ and correlation between $\mathrm{Ct}$ and tip speed ratio $(\lambda)$. The figure describes that $\mathrm{Ct}$ of rotor without guide vane increased at each velocity. There was increasing of $\mathrm{Ct}$ compared to the rotor with basic guide vane design. Maximum $\mathrm{Ct}$ that produced by the rotor without guide vane was 0.032 while the tip speed ratio $(\lambda)$ reached 0.42 and the rotor with basic design of guide vane attained the $\mathrm{Ct}$ of 0.038 at $10.7 \mathrm{~m} / \mathrm{s}$ and at the $\lambda$ of 0.48 , which means increaced about $17.23 \%$ compared to rotor without guide vane.

Other experiments used basic design of guide vane with additional tilt angle of $15^{\circ}$, maximum $\mathrm{Ct}$ of rotor was 0.047 at the $\lambda$ of 0.44 that is improves about $33.31 \%$ compared to maximum $\mathrm{Ct}$ of rotor without guide vane, however it was attained at the velocity of $8.6 \mathrm{~m} / \mathrm{s}$.

The Savonius rotor with the third design of guide vane with additional tilt angle of $30^{\circ}$, the $\mathrm{Ct}$ maximum reached up to 0.060 at the velocity of $8.6 \mathrm{~m} / \mathrm{s}$ and at the $\lambda$ of 0.50 , which means improves about $47.09 \%$ compared to the rotor without guide vane. And the last design of guide vane with additional of tilt angle of $45^{\circ}$, the $\mathrm{Ct}$ of Savonius rotor was attained up to 0.066 at the velocity of $8.6 \mathrm{~m} / \mathrm{s}$ and at the $\lambda$ of 0.53 . It was improved about $51.87 \%$.

Therefore, Ct started to decrease at velocity of $9.7 \mathrm{~m} / \mathrm{s}$, when the value of $\lambda$ increased accordingly with the increase of velocity. The decreace happened on the rotor with basic design guide vane with additional tilt angle of $15^{\circ}, 30^{\circ}$, and $45^{\circ}$. The decreace happened might because of the characteristic of the Savonius wind turbine that $\mathrm{Ct}$ increaces liniear due to the decrease of tip speed ratio $(\lambda)$. So that when the tip speed ratio value increaced, the $\mathrm{Ct}$ decreased as happening in the present study.

\section{Conclusion}

In present work, a series of experiment has been carried out. This experiment used two-blade Savonius wind turbine without guide vane and with various designs of guide vane, which were basic design of guide vane, basic design with additional tilt angle of $15^{\circ}$, basic design with additional tilt angle of $30^{\circ}$ and basic design with additional tilt angle of $45^{\circ}$. It can be concluded as follows:

1) The best design of guide vane to improve Savonius wind turbine performance is the basic design with additional tilt angle of $45^{\circ}$. The $\mathrm{Cp}$ that attained by turbine increases up to $65.89 \%$ compared without guide vane turbine.

2) It has been proven that the addition of guide vane support the improvement of the Savonius wind turbine. The guide vane helped to block up wind direction on to convex blade and directed it to concave blade. For various guide vane designs by adding tilt angle of $15^{\circ}, 30^{\circ}$ and $45^{\circ}$ improved higher performance of the Savonius rotor because they were able capture the wind and prevented the wind that might be escaped to the sides, upper, or bottom sides. It increased the wind speed that flows into the rotor and improving power of the rotor, so that the Savonius rotor met its efficiency.

3) Maximum improvement of $\mathrm{Cp}$ met its peak on the low velocities. It is related to the low aerodynamic characteristic of Savonius wind turbine. 
4) Coefficient of power (Cp) increased accordingly with the increase of wind velocity and at same time $\mathrm{Cp}$ increase with the increase of tip speed ratio $(\lambda)$ in this present study.

5) Torque coefficient $(\mathrm{Ct})$ decreased with the increasing of wind velocity (v) and tip speed ratio. However, Ct started to decreace on Savonius rotor with guide vane design plus tilt angle of $15^{\circ}, 30^{\circ}$, and $45^{\circ}$. It started to happen at the wind speed of $9.7 \mathrm{~m} / \mathrm{s}$ and at the $\lambda$ of 0.4902 for rotor with guide vane design plus $15^{\circ}$, at the $\lambda$ of 0.0 .5553 for rotor with guide vane plus $30^{\circ}$, and at the $\lambda$ of 0.5737 for the rotor with guide vane design plus $45^{\circ}$.

\section{References}

Akwa, J. V., Vielmo, H. A., \& Petry, A. P. (2012). A review on the performance of Savonius wind turbines. Renewable and Sustainable Energy Reviews, 16(5), 3054-3064. http://dx.doi.org/10.1016/j.rser.2012.02.056

Altan, B. D., Atılgan, M., \& Özdamar, A. (2008). An experimental study on improvement of a Savonius rotor performance with curtaining. Experimental thermal and fluid science, 32(8), 1673-1678. http://dx.doi.org/10.1016/j.expthermflusci.2008.06.006

Chong, W. T., Fazlizan, A., Pan, K. C., \& Poh, S. C. (2010). Design and Wind Tunnel Testing of a Savonius Wind Turbine Integrated with the Omni-Direction-Guide-Vane. Paper presented at the Proceedings of the Solar Conference.

Damak, A., Driss, Z., \& Abid, M. (2013). Experimental investigation of helical Savonius rotor with a twist of 180. Renewable Energy, 52, 136-142. http://dx.doi.org/10.1016/j.renene.2012.10.043

Hayashi, T., Li, Y., \& Suzuki, H. Y. (2004). Proceedings of European Wind Energy Conference and Exhibition. Wind tunnel test on a three stage out phase Savonius rotor, London, England.

Jeon, K. S., Jeong, J. I., Pan, J. K., \& Ryu, K. W. (2014). Effects of end plates with various shapes and sizes on helical Savonius wind turbines. Renewable Energy. http://dx.doi.org/10.1016/j.renene.2014.11.035

Kim, D., \& Gharib, M. (2013). Efficiency improvement of straight-bladed vertical-axis wind turbines with an upstream deflector. Journal of Wind Engineering and Industrial Aerodynamics, 115, 48-52. http://dx.doi.org/10.1016/j.jweia.2013.01.009

Mahmoud, N., El-Haroun, A., Wahba, E., \& Nasef, M. (2012). An experimental study on improvement of Savonius rotor performance. Alexandria Engineering Journal, 51(1), 19-25. http://dx.doi.org/10.1016/j.aej.2012.07.003

Maldonado, R., Huerta, E., Corona, J., Ceh, O., León-Castillo, A., Gómez-Acosta, M., \& Mendoza-Andrade, E. (2014). Design, Simulation and Construction of a Savonius Wind Rotor for Subsidized Houses in Mexico. Energy Procedia, 57, 691-697. http://dx.doi.org/10.1016/j.egypro.2014.10.224

Nasef, M., El-Askary, W., AbdEL-Hamid, A., \& Gad, H. (2013). Evaluation of Savonius rotor performance: static and dynamic studies. Journal of Wind Engineering and Industrial Aerodynamics, 123, 1-11. http://dx.doi.org/10.1016/j.jweia.2013.09.009

Ogawa, T., Tahara, K., \& Suzuki, N. (1986). Wind tunnel performance data of the Savonius rotor with circular guide vanes. Bulletin of JSME, 29(253), 2109-2114. NII-Electronic Library Service

Roy, S., \& Saha, U. K. (2015). Wind tunnel experiments of a newly developed two-bladed Savonius-style wind turbine. Applied Energy, 137, 117-125. http://dx.doi.org/10.1016/j.apenergy.2014.10.022

Sathyajith, M. (2006). Wind energy: fundamentals, resource analysis and economics: Springer Science \& Business Media.

Tong, W. (2010). Wind power generation and wind turbine design: WIT press. http://dx.doi.org/10.1016/j.egypro.2014.11.1080 


\section{Appendix A}

\section{Result of Voltage}

Table A. 1 Voltage Measurement Result of Savonius Wind Turbine without Guide Vane

\begin{tabular}{cccccc}
\hline Wind Speed $(\mathrm{m} / \mathrm{s})$ & 6.5 & 7.7 & 8.6 & 9.7 & 10.7 \\
\hline 1 & 0.97 & 1.76 & 3.03 & 3.95 & 6.04 \\
2 & 0.45 & 2 & 2.89 & 3.78 & 5.5 \\
3 & 0.34 & 1.61 & 3.11 & 4.95 & 6.17 \\
4 & 0.54 & 1.85 & 2.95 & 4.41 & 5.43 \\
5 & 1.01 & 1.79 & 3.62 & 4.21 & 5.76 \\
\hline Average & 0.66 & 1.80 & 3.12 & 4.26 & 5.78 \\
\hline
\end{tabular}

Table A. 2 Voltage Measurement Result of Savonius Wind Turbine with Basic Guide Vane Design

\begin{tabular}{cccccc}
\hline Wind Speed $(\mathrm{m} / \mathrm{s})$ & 6.5 & 7.7 & 8.6 & 9.7 & 10.7 \\
\hline 1 & 1.79 & 2.33 & 3.78 & 5.72 & 6.3 \\
2 & 1.81 & 2.56 & 3.58 & 5.5 & 6.76 \\
3 & 1.95 & 2.11 & 4.02 & 4.88 & 6.22 \\
4 & 1.68 & 2.31 & 3.94 & 5.03 & 7.24 \\
5 & 1.88 & 2.68 & 3.82 & 5.75 & 7.46 \\
\hline Average & 1.82 & 2.40 & 3.83 & 5.38 & 6.80 \\
\hline
\end{tabular}

Table A. 3 Voltage Measurement Result of Savonius Wind Turbine with Basic Guide Vane Design $+15^{\circ}$

\begin{tabular}{cccccc}
\hline Wind Speed $(\mathrm{m} / \mathrm{s})$ & 6.5 & 7.7 & 8.6 & 9.7 & 10.7 \\
\hline 1 & 2.21 & 3.02 & 5.89 & 6.57 & 7.67 \\
2 & 2.05 & 3.43 & 5.23 & 5.89 & 7.88 \\
3 & 2.79 & 3.78 & 5.17 & 6.39 & 7.94 \\
4 & 2.11 & 2.95 & 4.95 & 6.48 & 7.5 \\
5 & 2.41 & 3.63 & 4.88 & 6.95 & 7.39 \\
\hline Average & 2.31 & 3.36 & 5.22 & 6.46 & 7.68 \\
\hline
\end{tabular}

Table A. 4 Voltage Measurement Result of Savonius Wind Turbine with Basic Guide Vane Design $+30^{\circ}$

\begin{tabular}{cccccc}
\hline Wind Speed $(\mathrm{m} / \mathrm{s})$ & 6.5 & 7.7 & 8.6 & 9.7 & 10.7 \\
\hline 1 & 3.04 & 4.75 & 6.27 & 7.34 & 8.75 \\
2 & 3.02 & 4.8 & 6.04 & 7.23 & 8.5 \\
3 & 3.25 & 4.93 & 5.73 & 7.86 & 8.97 \\
4 & 2.97 & 4.56 & 7.39 & 7.84 & 9.64 \\
5 & 3.22 & 5.21 & 6.11 & 8.08 & 9.2 \\
\hline Average & 3.10 & 4.85 & 6.31 & 7.67 & 9.01 \\
\hline
\end{tabular}

Table A. 5 Voltage Measurement Result of Savonius Wind Turbine with Basic Guide Vane Design $+45^{\circ}$

\begin{tabular}{cccccc}
\hline Wind Speed $(\mathrm{m} / \mathrm{s})$ & 6.5 & 7.7 & 8.6 & 9.7 & 10.7 \\
\hline 1 & 3.52 & 5.13 & 6.72 & 8.65 & 10.15 \\
2 & 3.73 & 4.84 & 6.65 & 8.61 & 9.84 \\
3 & 3.69 & 5.96 & 6.39 & 8.21 & 9.79 \\
4 & 4.47 & 4.98 & 7.01 & 8.25 & 9.94 \\
5 & 4.08 & 5.05 & 7.13 & 8.17 & 9.77 \\
\hline Average & 3.90 & 5.19 & 6.78 & 8.38 & 9.90 \\
\hline
\end{tabular}




\section{Appendix B}

Result of Power

Table B1. Power Calculation of Savonius Wind Turbine without Guide Vane

\begin{tabular}{ccccccc}
\hline No & $\begin{array}{c}\text { Velocity } \\
(\mathrm{m} / \mathrm{s})\end{array}$ & $\begin{array}{c}\text { Rotation Speed } \\
(\mathrm{rpm})\end{array}$ & $\begin{array}{c}\text { Voltage } \\
(\text { volt })\end{array}$ & $\begin{array}{c}\text { Resistance } \\
(\text { ohm })\end{array}$ & $\begin{array}{c}\text { Current } \\
\text { (ampere) }\end{array}$ & $\begin{array}{c}\text { Power } \\
(\text { watt })\end{array}$ \\
\hline 1 & 6.5 & 147 & 0.66 & 100 & 0.00662 & 0.0043824 \\
2 & 7.7 & 193 & 1.80 & 100 & 0.01802 & 0.032472 \\
3 & 8.6 & 238 & 3.12 & 100 & 0.0312 & 0.097344 \\
4 & 9.7 & 315 & 4.26 & 100 & 0.0426 & 0.181476 \\
5 & 10.7 & 423 & 5.78 & 100 & 0.0578 & 0.334084 \\
\hline
\end{tabular}

Table B2. Power Calculation of Savonius Wind Turbine with Basic Guide Vane Design

\begin{tabular}{ccccccc}
\hline No & $\begin{array}{c}\text { Velocity } \\
(\mathrm{m} / \mathrm{s})\end{array}$ & $\begin{array}{c}\text { Rotation Speed } \\
(\mathrm{rpm})\end{array}$ & $\begin{array}{c}\text { Voltage } \\
(\text { volt })\end{array}$ & $\begin{array}{c}\text { Resistance } \\
(\mathrm{ohm})\end{array}$ & $\begin{array}{c}\text { Current } \\
\text { (ampere) }\end{array}$ & $\begin{array}{c}\text { Power } \\
\text { (watt) }\end{array}$ \\
\hline 1 & 6.5 & 169 & 1.82 & 100 & 0.01822 & 0.033197 \\
2 & 7.7 & 227 & 2.40 & 100 & 0.02398 & 0.057504 \\
3 & 8.6 & 309 & 3.83 & 100 & 0.03828 & 0.146536 \\
4 & 9.7 & 393 & 5.38 & 100 & 0.05376 & 0.289014 \\
5 & 10.7 & 484 & 6.80 & 100 & 0.06796 & 0.461856 \\
\hline
\end{tabular}

Table B3. Power Calculation of Savonius Wind Turbine with Basic Guide Vane Design $+15^{\circ}$

\begin{tabular}{ccccccc}
\hline No & $\begin{array}{c}\text { Velocity } \\
(\mathrm{m} / \mathrm{s})\end{array}$ & $\begin{array}{c}\text { Rotation Speed } \\
(\mathrm{rpm})\end{array}$ & $\begin{array}{c}\text { Voltage } \\
(\text { volt })\end{array}$ & $\begin{array}{c}\text { Resistance } \\
(\mathrm{ohm})\end{array}$ & $\begin{array}{c}\text { Current } \\
\text { (ampere) }\end{array}$ & $\begin{array}{c}\text { Power } \\
\text { (watt) }\end{array}$ \\
\hline 1 & 6.5 & 203 & 2.31 & 100 & 0.02314 & 0.053546 \\
2 & 7.7 & 279 & 3.36 & 100 & 0.03362 & 0.11303 \\
3 & 8.6 & 357 & 5.22 & 100 & 0.05224 & 0.272902 \\
4 & 9.7 & 452 & 6.46 & 100 & 0.06456 & 0.416799 \\
5 & 10.7 & 554 & 7.68 & 100 & 0.07676 & 0.58921 \\
\hline
\end{tabular}

Table B.4 Power Calculation of Savonius Wind Turbine with Basic Guide Vane Design $+30^{\circ}$

\begin{tabular}{ccccccc}
\hline No & $\begin{array}{c}\text { Velocity } \\
(\mathrm{m} / \mathrm{s})\end{array}$ & $\begin{array}{c}\text { Rotation Speed } \\
(\mathrm{rpm})\end{array}$ & $\begin{array}{c}\text { Voltage } \\
(\text { volt })\end{array}$ & $\begin{array}{c}\text { Resistance } \\
(\text { ohm })\end{array}$ & $\begin{array}{c}\text { Current } \\
(\text { ampere })\end{array}$ & $\begin{array}{c}\text { Power } \\
(\text { watt })\end{array}$ \\
\hline 1 & 6.5 & 245 & 3.10 & 100 & 0.031 & 0.0961 \\
2 & 7.7 & 331 & 4.85 & 100 & 0.0485 & 0.235225 \\
3 & 8.6 & 413 & 6.31 & 100 & 0.06308 & 0.397909 \\
4 & 9.7 & 512 & 7.67 & 100 & 0.0767 & 0.588289 \\
5 & 10.7 & 597 & 9.01 & 100 & 0.09012 & 0.812161 \\
\hline
\end{tabular}

Table B5. Power Calculation of Savonius Wind Turbine with Basic Guide Vane Design $+45^{\circ}$

\begin{tabular}{ccccccc}
\hline No & $\begin{array}{c}\text { Velocity } \\
(\mathrm{m} / \mathrm{s})\end{array}$ & $\begin{array}{c}\text { Rotation Speed } \\
(\mathrm{rpm})\end{array}$ & $\begin{array}{c}\text { Voltage } \\
(\text { volt })\end{array}$ & $\begin{array}{c}\text { Resistance } \\
(\mathrm{ohm})\end{array}$ & $\begin{array}{c}\text { Current } \\
\text { (ampere) }\end{array}$ & $\begin{array}{c}\text { Power } \\
(\text { watt })\end{array}$ \\
\hline 1 & 6.5 & 272 & 3.90 & 100 & 0.03898 & 0.151944 \\
2 & 7.7 & 351 & 5.19 & 100 & 0.05192 & 0.269569 \\
3 & 8.6 & 434 & 6.78 & 100 & 0.0678 & 0.459684 \\
4 & 9.7 & 529 & 8.38 & 100 & 0.08378 & 0.701909 \\
5 & 10.7 & 627 & 9.90 & 100 & 0.09898 & 0.979704 \\
\hline
\end{tabular}




\section{Appendix C}

\section{Data Result of Power Coefficient}

Table C1. Power Coefficient of Savonius Wind Turbine without Guide Vane

\begin{tabular}{ccccc}
\hline No & Velocity (v) & Power (p) & Po & CP \\
\hline 1 & 6.5 & 0.0043824 & 5.794248 & 0.0007563 \\
2 & 7.7 & 0.032472 & 9.362022 & 0.0034685 \\
3 & 8.6 & 0.097344 & 13.11574 & 0.0074219 \\
4 & 9.7 & 0.181476 & 18.78608 & 0.0096601 \\
5 & 10.7 & 0.334084 & 25.29075 & 0.0132097 \\
\hline
\end{tabular}

Table C2. Power Coefficient of Savonius Wind Turbine without Guide Vane

\begin{tabular}{ccccc}
\hline No & Velocity (v) & Power (p) & Po & CP \\
\hline 1 & 6.5 & 0.0331968 & 5.794248 & 0.0057293 \\
2 & 7.7 & 0.057504 & 9.362022 & 0.0061423 \\
3 & 8.6 & 0.1465358 & 13.11574 & 0.0111725 \\
4 & 9.7 & 0.2890138 & 18.78608 & 0.0153845 \\
5 & 10.7 & 0.4618562 & 25.29075 & 0.0182619 \\
\hline
\end{tabular}

Table C3. Power Coefficient of Savonius Wind Turbine without Guide Vane with Basic Guide Vane $+15^{\circ}$

\begin{tabular}{ccccc}
\hline No & Velocity (v) & Power (p) & Po & CP \\
\hline 1 & 6.5 & 0.053546 & 5.794248 & 0.0092412 \\
2 & 7.7 & 0.1130304 & 9.362022 & 0.0120733 \\
3 & 8.6 & 0.2729018 & 13.11574 & 0.0208072 \\
4 & 9.7 & 0.4167994 & 18.78608 & 0.0221866 \\
5 & 10.7 & 0.5892098 & 25.29075 & 0.0232974 \\
\hline
\end{tabular}

Table C4. Power Coefficient of Savonius Wind Turbine without Guide Vane with Basic Guide Vane $+30^{\circ}$

\begin{tabular}{ccccc}
\hline No & Velocity (v) & Power (p) & Po & CP \\
\hline 1 & 6.5 & 0.0961 & 5.794248 & 0.0165854 \\
2 & 7.7 & 0.235225 & 9.362022 & 0.0251254 \\
3 & 8.6 & 0.3979086 & 13.11574 & 0.0303383 \\
4 & 9.7 & 0.588289 & 18.78608 & 0.0313151 \\
5 & 10.7 & 0.8121614 & 25.29075 & 0.032113 \\
\hline
\end{tabular}

Table C5. Power Coefficient of Savonius Wind Turbine without Guide Vane with Basic Guide Vane $+45^{\circ}$

\begin{tabular}{ccccc}
\hline No & Velocity (v) & Power (p) & Po & CP \\
\hline 1 & 6.5 & 0.151944 & 5.794248 & 0.0262233 \\
2 & 7.7 & 0.2695686 & 9.362022 & 0.0287938 \\
3 & 8.6 & 0.459684 & 13.11574 & 0.0350483 \\
4 & 9.7 & 0.7019088 & 18.78608 & 0.0373632 \\
5 & 10.7 & 0.979704 & 25.29075 & 0.0387376 \\
\hline
\end{tabular}




\section{Appendix D}

\section{Data Result of Tip Speed Ratio}

Table D1. TSR without Guide Vane

\begin{tabular}{cccc}
\hline No & Velocity (v) & n & TSR \\
\hline 1 & 6.5 & 147 & 0.2359816 \\
2 & 7.7 & 193 & 0.26403445 \\
3 & 8.6 & 238 & 0.29098631 \\
4 & 9.7 & 315 & 0.34165803 \\
5 & 10.7 & 423 & 0.41550823 \\
\hline
\end{tabular}

Table D2. TSR Basic Guide Vane

\begin{tabular}{cccc}
\hline No & Velocity (v) & n & TSR \\
\hline 1 & 6.5 & 169 & 0.27129857 \\
2 & 7.7 & 227 & 0.31054829 \\
3 & 8.6 & 309 & 0.37779315 \\
4 & 9.7 & 393 & 0.42625907 \\
5 & 10.7 & 484 & 0.47542786 \\
\hline
\end{tabular}

Table D3. TSR Basic Guide Vane $+15^{\circ}$

\begin{tabular}{cccc}
\hline No & Velocity (v) & n & TSR \\
\hline 1 & 6.5 & 203 & 0.32587935 \\
2 & 7.7 & 279 & 0.38168711 \\
3 & 8.6 & 357 & 0.43647947 \\
4 & 9.7 & 452 & 0.49025216 \\
5 & 10.7 & 554 & 0.54418808 \\
\hline
\end{tabular}

Table D4. TSR Basic Guide Vane $+30^{\circ}$

\begin{tabular}{cccc}
\hline No & Velocity (v) & n & TSR \\
\hline 1 & 6.5 & 245 & 0.39330266 \\
2 & 7.7 & 331 & 0.45282593 \\
3 & 8.6 & 413 & 0.50494684 \\
4 & 9.7 & 512 & 0.55532988 \\
5 & 10.7 & 597 & 0.58642651 \\
\hline
\end{tabular}

Table D5.TSR Basic Guide Vane $+45^{\circ}$

\begin{tabular}{cccc}
\hline No & Velocity (v) & n & TSR \\
\hline 1 & 6.5 & 272 & 0.43664622 \\
2 & 7.7 & 351 & 0.48018701 \\
3 & 8.6 & 434 & 0.5306221 \\
4 & 9.7 & 529 & 0.57376857 \\
5 & 10.7 & 627 & 0.61589518 \\
\hline
\end{tabular}

\section{Copyrights}

Copyright for this article is retained by the author(s), with first publication rights granted to the journal.

This is an open-access article distributed under the terms and conditions of the Creative Commons Attribution license (http://creativecommons.org/licenses/by/3.0/). 